\title{
Emergency Power Failure
}

National Cancer Institute

\section{Source}

National Cancer Institute. Emergency Power Failure. NCI Thesaurus. Code C63212.

Problem associated with the failure of the facility's emergency power backup system(s) including generators and/or interruptible power systems (UPS). 